DOI: 10.32844/2222-5374-2020-104-2.37

УДК: 342.9

Терещенко О. А.,

здобувач Науково-дослідного інституту публічного права

\title{
ЗАРУБІЖНИЙ ДОСВІД ПУБЛІЧНОГО АДМІНІСТРУВАННЯ ЕЛЕКТРОННОГО УРЯДУВАННЯ СУДОВОЇ ВЛАДИ В УКРАЇНІ
}

На сьогоднішній день, тема публічного адміністрування електронного урядування судової влади в Україні по справжньому викликає особливий науковий інтерес. Зарубіжний досвід розвинених демократичних країн світу відіграєособливуроль, оскількидозволяєперейнятипозитивнінапращювання будь якої сфери публічно-правових відносин для нашої держави. Україна вже почала етап публічного адміністрування електронного урядування судової влади,однакякібудьяка «молода»системавонамаєряднедоліків,якінеобхідно виправляти. Розвиток сучасних комп'ютерних технологій розвивається надпотужними темпами, що на сьогоднішній день вже дозволяє замінити механічну людську працю. Тому хочемо ми того, чи ні інформатизація та технологізація усіх сфер публічного адміністрування являється необхідним етапом становлення та розвитку нашого суспільства. Зарубіжний досвід сусідніх країн світу, дозволяє нам рівнятися на них та переймати їхній досвід. Так, становлення публічного адміністрування електронного урядування судової влади викликає закономірний інтерес у таких державах, як Австрія, Велика Британія, Німеччина, Польща, Естонія, Норвегія в яких електронне судочинство вже здійснюється на досить високому рівні. Метою статті є розкриття тематики зарубіжного досвіду публічного адміністрування електронного урядування судової влади. В статті визначено, що запозичення та впровадження позитивного зарубіжного досвіду публічного адміністрування електронного урядування судової влади для України включає виокремлення деяких аспектів електронної діяльності судових органів сучасних, демократичних країн світу й застосування їх у вітчизняній судовій системі, зокрема ми виділили для запозичення досвід Естонії так він найбільще підпадає під втілення таких важливих аспектів як: економія грошей (довгострокова), економія часу економія простору, надання розширеного доступу до суду для суддів, адвокатів та учасників судових процесів. Зроблено висновок, що впровадження зарубіжного досвід публічного адміністрування електронного урядування судової влади для нашої держави: 1) спрощений та швидший доступ до можливий тільки за допомогою електронного урядування судової системи; 2) необхідне впровадження подання електронних заявок на судовий розгляд; 3) можливість дистанційної форми розгляду судової справи; 4) створення електронної картотеки законних проступків громадян; 5) створення окремих он-лайн сторінок, де кожен може ознайомитися із матеріалами справи; 6) формування онлайн центрів з консультування громадян у сфері онлайн-правосуддя. 
Ключові слова: електронне урядування, зарубіжний досвід, інформатизація, публічне адміністрування, суб'єкти, судова влада, технологізація.

Актуальність теми. На сьогоднішній день, тема публічного адміністрування електронного урядування судової влади в Україні по справжньому викликає особливий науковий інтерес. Зарубіжний досвід розвинених демократичних країн світу відіграє особливу роль, оскільки дозволяє перейняти позитивні напрацювання будь якої сфери публічноправових відносин для нашої держави.

Україна вже почала етап публічного адміністрування електронного урядування судової влади (наприклад доволі успішно працює система (CITC), однак як і будь яка «молода» система вона має ряд недоліків, які необхідно виправляти.

Розвиток сучасних комп'ютерних технологій розвивається надпотужними темпами, що на сьогоднішній день вже дозволяє замінити механічну людську працю. Тому хочемо ми того, чи ні інформатизація та технологізація усіх сфер публічного адміністрування являється необхідним етапом становлення та розвитку нашого суспільства.

Зарубіжний досвід сусідніх країн світу, дозволяє нам рівнятися на них та переймати їхній досвід. Так, становлення публічного адміністрування електронного урядування судової влади викликає закономірний інтерес у таких державах, як Австрія, Велика Британія, Німеччина, Польща, Естонія, Норвегія в яких електронне судочинство вже здійснюється на досить високому рівні.

Отже, вищезазначене зумовлює доцільність дослідження Зарубіжний досвід публічного адміністрування електронного урядування судової влади в Україні.

Огляд останніх досліджень. Опосередковано дослідженням проблематики зарубіжного досвіду публічного адміністрування електронного урядування судової влади займалися такі вчені, як: В. Авер'янов, В. Басс, Ю. Битяк, В. Галунько, М. Дамірчиєв, В. Заросило, В. Колпаков, О. Кузьменко, Р. Мельник, Л. Миськів, А. Нонко, О. Радишевська, Є. Соболь, С. Стеценко, В. Ткаченка, О. Тихомиров, Т. Цуркан, В. Шкарупа, García de Enterría, Posada Martínez Lopez-Muñiz, Caroline Meller-Hannich, Kanton Bern в та інші. Проте вони не зосереджували свої наукові пошуки на проблемі компаративістичної характеристики у цій сфері.

Метою статті $є$ розкриття тематики зарубіжного досвіду публічного адміністрування електронного урядування судової влади.

Виклад основних положень. Аналізу застосування інформаційних технологій у діяльності судів присвячено небагато досліджень. До того ж вони не повною мірою відбивають практику застосування комп'ютерних технологій і тенденції подальшого їх використання.

Функціональним призначенням застосування інформаційних технологій можна виділити такі завдання в забезпеченні та організації діяльності судів: - автоматизацію та раціоналізацію окремих трудових операцій в діяльності суддів і працівників апарату судів, забезпечення наукової організації праці (наприклад, використання шаблонів при виготовленні 
процесуальних документів і текстів судових рішень, автоматизація лінгвістичної перевірки текстів, друк документів і т. ін.); - комплексну автоматизацію судового діловодства (автоматизація реєстрації справ і матеріалів, підготовка процесуальних документів, здійснення процесуального листування, планування засідань і використання залів судових засідань, передання справ в архів і т. ін.); - забезпечення адміністративного управління діяльністю суду (оперативне отримання відомостей, аналіз проходження і стану справ у суді - контроль процесуальних строків, аналіз завантаження і управління планами суддів, автоматизація розподілу судових справ, автоматизація бухгалтерського обліку та матеріально-господарської діяльності, інформаційне забезпечення закупівель для потреб судів і т. ін.); - формування державної та відомчої судової статистики (автоматизація підготовки, збору, обробки, узагальнення, аналізу, надання та поширення статистичної та іншої звітності; реалізація інформаційних процесів безпосередньо в судочинстві - залі судового засідання: наочне надання всім учасникам процесу потрібної інформації (зображення, тексти, документи, аудіо- та відеозаписи, речові докази), забезпечення захисту й обвинувачення можливості підключення мобільних комп'ютерів, які можуть бути інтегровані в інформаційну мережу залу, аудіо- і відеозапис судових засідань і т. ін.); - реалізація технологічних способів доступу громадян до правосуддя (дистанційна участь сторін у судовому процесі, застосування інтерактивних технологій інформаційної взаємодії (електронна пошта, чати) і т. ін.); - формування електронного архіву судових документів [1].

Рада підтримала проект закону (№ 3985) про поетапне впровадження Єдиної судової інформаційно-телекомунікаційної системи. За те, щоб усі 15 підсистем Єдиної судової інформаційно-телекомунікаційної системи (ECITC) запускали поетапно, проголосували 250 народних депутатів. 3роблено це тому, що повна готовність системи, як відзначалося, - це справа кількох років та й то за наявності достатнього фінансування. Зараз деякі підсистеми вже майже готові до експлуатації, а деякі перебувають лише на етапі розробки, тому й пропонується вводити ЄСITC в експлуатацію частинами. Правда, дехто з депутатів висловлював занепокоєння, що це призведе до зволікання з цифровізацією роботи судової системи. Хоча, як зазначається в пояснювальній записці до законопроекту, Єдину судову інформаційно-телекомунікаційну систему створювали для формування єдиного інформаційного простору для органів та установ системи правосуддя, міжвідомчого обігу інформації, обміну нею, забезпечення максимальної прозорості й відкритості системи правосуддя для суспільства, прискорення розгляду судових справ та проваджень, автоматизації роботи, переходу на електронні версії документів у судовому провадженні, оцифровування судових архівів тощо. Загалом же дана система, про яку говорять уже досить давно, покликана підвищити ефективність судових органів шляхом впровадження сучасних технологій у їхню повсякденну діяльність і спростити комунікацію учасників судових процесів та їхніх представників із судовими органами. ЄСТTC має діяти в судах, Вищій раді правосуддя, Раді суддів, Вищій кваліфікаційній комісії суддів, Державній судовій адміністрації, на підприємствах, що належать до сфери правосуддя, в Національній школі суддів України. Й ця система 
мала запрацювати давно, проте цьому завадила низка факторів, зокрема неготовність усього обсягу модулів (підсистем) ЄCITC до повноцінного, стабільного функціонування. Введення Єдиної судової інформаційнотелекомунікаційної системи на початку 2019 року в стані готовності, який був на той час, за оцінками Вищої ради правосуддя та окремих експертів призвело б до протилежних результатів, ніж ті, заради яких цю систему створюють. Після введення в дію підсистеми ЄСITC «Електронний суд» в судів буде можливість в електронному вигляді направляти сторонам документи, що дозволить економити кошти держави та учасників справ. Єдина підсистема електронного діловодства судів, органів та установ системи правосуддя складається з 5 модулів: Електронний суд, Електронне діловодство, «Автоматизований розподіл» судових справ між суддями, «Електронний архів» та «Судова статистика» [2].

Таким чином, електронна система ЄCITC повинна підвищити ефективність судових органів та зробити їх доступними для громадян України, однак вище проаналізована інформація дає можливість стверджувати, що і вона містить ряд недоліків, які необхідно допрацьовувати.

У наш час життя відбувається швидко, і судові процедури наріжні камені демократії - повинні бути такими ж швидкими. Завдяки повністю автоматизованим судовим процесам та засобам електронного спілкування - так званим рішенням електронного правосуддя - Естонія має одну 3 найефективніших судових систем у світі. Центральна інформаційна система - електронна картотека - забезпечує огляд різних фаз кримінальних, проступкових, цивільних та адміністративних процедур, судових рішень та процесуальних дій для всіх залучених сторін, включаючи громадянина. Уряд Естонії в 2005 році запровадив розробку електронного файлу, визнавши необхідність розбити інформаційні шахти, які функціонували незалежно один від одного. E-File впровадив Центр реєстрів та інформаційних систем (RIK), який досі відповідає за розробку, адміністрування та підтримку системи. Як інтегрована система, e-File забезпечує одночасний обмін інформацією між інформаційними системами різних сторін: поліцією, прокуратурою, судами, тюрмами, наглядовим наглядом, судовими приставами, системою правової допомоги, податковою та митною комісією, державним центром обслуговування акцій, юристами та громадян. E-File економить час і гроші, оскільки дані вводяться лише один раз, а спілкування між сторонами здійснюється електронно. У 2006 році була запущена Судова інформаційна система (KIC), яка пропонувала одну інформаційну систему для всіх типів судових справ: естонські суди 1-ї та 2-ї інстанцій та Верховний суд. KIS дозволяє реєструвати судові справи, слухання та рішення, автоматичний розподіл справ суддями, створення повісток, публікацію судових рішень на офіційному веб-сайті та збір метаданих. KIS останнього покоління включає нові класифікатори, що базуються на потребах судів, наприклад типи справ, категорії справ та підкатегорії. Як інструмент для суддів, КІС другого покоління представляє цінну еволюцію, в якій проводяться обшуки на основі фаз провадження, видача нагадувань та моніторинг тривалості часу, проведеного на кожному етапі [3]. 
Таким чином, на нашу думку найбільше для запровадження в Україні підпадає запровадження зарубіжного досвіду Естонії так він найбільше підходить під втілення таких важливих аспектів як: економія грошей (довгострокова), економія часу економія простору, надання розширеного доступу до суду для суддів, адвокатів та учасників судових процесів.

Однак, бути цифровим суспільством означає піддатися кіберзагрозам. Завдяки значним інвестиціям в інфраструктуру кібербезпеки, Естонія розробила великий досвід у цій галузі, ставши одним із найбільш визнаних та найцінніших міжнародних експертів з кібербезпеки. Після досвіду Естонії 3 кібер-атаками 2007 року була розроблена масштабована технологія блокчейну, щоб забезпечити цілісність даних, що зберігаються в державних сховищах, і захистити свої дані від інсайдерських загроз. Естонія стала приймачем Кооперативного центру передового досвіду кіберзахисту НАТО та Європейського IT-агентства [3].

Таким чином,якми бачимо впровадження публічногоадміністрування електронного урядування судової влади має не тільки переваги, а й недоліки. Однією з таких є кіберзагрози, тому слід паралельно працювати у напрямку забезпечення безпеки інформації, яка зберігається на віртуальних сховищах.

Слід розуміти, що судовий процес значно спрощується, коли обидві сторони провадження подають документи в електронному вигляді, що робить використання електронної судової системи особливо зручним. Наразі системою активно користуються як фізичні, так і юридичні особи, а також адвокати та їх помічники. 3 усіх користувачів порталу, за підрахунками, юридичні особи складають майже $12 \%$, адвокати та їх помічники $10 \%$, а найбільша частка - 78\% - фізичні особи, литовські та іноземні громадяни. Активно розвиває цей напрямок і Норвегія, що займає друге місце у використанні IT-технологій в державних сферах. У бюджеті на 2017 рік значні кошти були закладені на впровадження електронно-цифрових технологій в судах. Раніше обмін документами в судах здійснювався поштою і через електронний портал. Електронний портал - це закрита система, тому використання електронно-цифрового підпису не потрібно. Відповідно до цього країни, які впроваджують елементи електронного суду, повною мірою не реалізували його (за винятком, можливо, тільки Сінгапуру, де судочинство повністю здійснюється без паперових носіїв), тому під поняттям «електронний суд» можна мати на увазі різні технології, які застосовуються в судочинстві. Багато з них в Україні вже використовуються і показали свою ефективність [4].

Таким чином, інформатизація та високотехнологічний захист від кібератак є запорукою доступності, незалежності та ефективності сучасної судової системи Норвегії.

У Німеччині від пілотного законопроекту до ідеального функціонування системи електронного правосуддя в цивільних судах знадобилось 10 років. Там діє Електронна судова та адміністративна поштова скринька (EGVP) - стандарт, який використовується німецькими судами та іншими органами влади для надійної та законної передачі повідомлень через транспортний протокол комп'ютерного інтерфейсу інтернет-сервісів 
(OSCI). В електронних правових операціях електронний підпис використовується необов'язково [5].

Відповідно і в цій системі не обійшлося без критики та спірних моментів. Для EGVP судова влада також розробила власне програмне забезпечення та надала його для безкоштовного завантаження, так званого «клієнта EGVP» або «програмного забезпечення для громадянина-клієнта EGVP». Це програмне забезпечення EGVP було запрограмовано на базі Java, подальший розвиток якої було припинено з 1 січня 2016 р. в рамках змін у доступі до електронної комерції з 1 січня 2016 р. - Закон про сприяння електронним правам [5].

Таким чином, електронний суд, адміністративна поштова скринька та непотрібність використання електронного цифрового підпису $\epsilon$ відмінністю для судової влади Німеччини.

Спрощений та швидший доступ до судової системи вважається однією з головних переваг електронних подань. Однак це передбачає добре розроблений та збалансований набір правил та процедур. Розглядаючи розглянуті системи загального права, стає зрозумілим, що до необхідності автентифікації та захисту даних можна підходити по-різному. Подання документів у Федеральний суд Австралії навіть не вимагає реєстрації. Уся необхідна інформація буде отримана з отриманої інформації та сукупного онлайн-платежу. Як показано, американські суди, які пропонують подання електронних заявок, демонструють загальноприйняту практику, згідно 3 якою майбутні реєстратори повинні реєструватися в судах, щоб отримати унікальний логін та пароль. Використання цієї конфіденційної інформації для подання документів забезпечує необхідну ідентифікацію позивача. Для подолання вимог письмового підпису, які постулюють автентифікацію документа, часто існують угоди, де використання унікального логіна у поєднанні 3 відповідним паролем становить електронний підпис. У поєднанні 3 системою онлайн-платежів за непередбачені збори за подання, такий підхід виявляється набагато зручнішим для користувачів і, отже, здатним залучити громадськість до електронних подань [6].

Таким чином, можемо зробити такі висновки щодо впровадження зарубіжного досвід публічного адміністрування електронного урядування судової влади для нашої держави: 1) спрощений та швидший доступ до можливий тільки за допомогою електронного урядування судової системи; 2) необхідне впровадження подання електронних заявок на судовий розгляд; 3) можливість дистанційної форми розгляду судової справи; 4) створення електронної картотеки законних проступків громадян; 5) створення окремих он-лайн сторінок, де кожен може ознайомитися із матеріалами справи; 6) формування онлайн центрів з консультування громадян у сфері онлайн-правосуддя.

Отже, запозичення та впровадження позитивного зарубіжного досвіду публічного адміністрування електронного урядування судової влади для України включає виокремлення деяких аспектів електронної діяльності судових органів сучасних, демократичних країн світу й застосування їх у вітчизняній судовій системі, зокрема ми виділили для запозичення досвід Естонії так він найбільше підпадає під втілення таких важливих 
аспектів як: економія грошей (довгострокова), економія часу економія простору, надання розширеного доступу до суду для суддів, адвокатів та учасників судових процесів.

\section{СПИСОК ВИКОРИСТАНИХ ДЖЕРЕЛ}

1. Чаплинский В. Организационно-правовое обеспечение информатизации судов общей юрисдикции областного уровня: Библиотека диссертаций. 2008. URL: http://www.dslib.net/admin-pravo/organizacionnopravovoe-obespechenie-informatizacii-sudov-obwej-jurisdikcii.html

2. «Електронний суд» запускатимуть частинами. Юридичні новини України. 2020. URL: https://lexinform.com.ua/zakonodavstvo/elektronnyjsud-zapuskatymut-chastynamy/

3. We have built a digital society and we can show you how. 2020. URL: https://e-estonia.com/

4. Голубєва Н. Електронне правосуддя: Україна і світовий досвід впро-вадження. 2020. URL: http://loyer.com.ua/uk/elektronne-pravosuddyaukrayina-i-svitovij-dosvid-vprovadzhennya/

5. Elektronisches Gerichts- und Verwaltungspostfach. Wikipedia. Die freie En-zyklopadie. 2019. URL:https://de.wikipedia.org/wiki/Elektronisches_ Gerichts-_und_Verwaltungspostfach

6. Courts and tribunals judiciary. 2020. URL: https://www.judiciary.uk/ about-the-judiciary/the-judiciary-the-government-and-the-constitution/judacc-ind/justice-sys-and-constitution/

\section{O. Tereshchenko}

\section{FOREIGN EXPERIENCE OF PUBLIC ADMINISTRATION OF ELECTRONIC GOVERNANCE OF THE JUDICIARY IN UKRAINE}

To date, the topic of public administration of e-government in Ukraine is of real scientific interest. The foreign experience of the developed democracies of the world plays a special role, as it allows us to adopt the positive developments of any sphere of public relations for our state. Ukraine has already begun the stage of public administration of e-government in the judiciary, but like any "young" system, it has a number of shortcomings that need to be addressed. The development of modern computer technology is developing at a rapid pace, which today allows us to replace mechanical human labor. Therefore, we want whether or not the informatization and technologicalization of all areas of public administration is a necessary stage in the formation and development of our society. Foreign experience of neighboring countries allows us to emulate them and adopt their experience. Thus, the formation of public administration of e-government of the judiciary is of natural interest in countries such as Austria, Great Britain, Germany, Poland, Estonia, Norway, where e-justice is already carried out at a fairly high level. The purpose of the article is to reveal the topic of foreign experience of public administration of e-government of the judiciary. The article stipulates that borrowing and implementing positive foreign experience of public administration of e-government of the judiciary for Ukraine includes highlighting some aspects of e-activity of judicial bodies of modern, democratic countries and their application in the domestic judiciary, in 
particular we falls under the implementation of such important aspects as: saving money (long-term), saving time, saving space, providing extended access to court for judges, lawyers and litigants. It is concluded that the introduction of foreign experience of public administration of e-government of the judiciary for our state: 1) simplified and faster access to possible only through e-government of the judiciary; 2) it is necessary to introduce the submission of electronic applications for trial; 3) the possibility of a remote form of court proceedings; 4) creation of an electronic file of legal misdemeanors of citizens; 5) creation of separate online pages, where everyone can get acquainted with the case materials; 6) formation of online centers for advising citizens in the field of online justice.

Keywords: e-government, foreign experience, informatization, public administration, subjects, judiciary, technologization. 